\title{
PENGARUH PENAMBAHAN ASAM HUMAT PADA PAKAN MENGANDUNG KADMIUM (Cd) DARI KERANG HIJAU TERHADAP BIOEUMINASI Cd, STATUS KESEHATAN, DAN PERTUMBUHAN IKAN KAKAP PUTIH Lates calcarifer
}

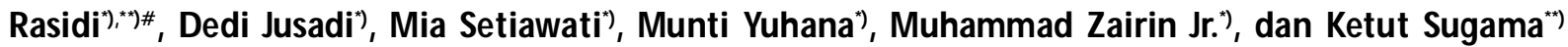 \\ *) Departemen Budidaya, Fakultas Kelautan dan Perikanan, Institut Pertanian Bogor \\ Kampus IPB Darmaga, Jalan Agatis, Babakan, Kec. Dramaga, Kota Bogor, Jawa Barat 16128 \\ *) Pusat Riset Perikanan \\ Gedung BRSDM KP II, JI. Pasir Putih II, Ancol Timur, Jakarta 14430 \\ E-mail: siflounder@gmail.com; dedidj@ ipb.ac.id
}

(Naskah diterima: 13 Agustus 2019; Revisi final: 28 Januari 2020; Disetujui publikasi: 28 Januari 2020)

\begin{abstract}
ABSTRAK
Asam humat (AH) terdiri atas AH alami (AHA) dan sintetik (AHS), namun efektivitasnya sebagai feed additive pada pakan ikan kakap putih belum dikaji. Tujuan penelitian ini untuk mengetahui efektivitas penambahan AH pada pakan yang mengandung kadmium (Cd) dari kerang hijau Perna viridis terhadap status kesehatan dan pertumbuhan ikan kakap putih, Lates calcarifer. Percobaan dirancang menggunakan rancangan acak lengkap (RAL) dengan lima perlakuan dan tiga ulangan. Perlakuan terdiri atas lima pakan uji mengandung AH yang berbeda, yaitu $0 ; 1.600 ; 10.000$; dan $20.000 \mathrm{mg} \mathrm{kg}^{-1}(\mathrm{AHA})$ dan sebagai pembanding menggunakan AHS sebesar $1.600 \mathrm{mg} \cdot \mathrm{kg}^{-1}$ pakan. Benih ikan kakap putih $(4,18 \pm 0,25 \mathrm{~g})$ dipelihara dalam akuarium ukuran $80 \mathrm{~cm} \times 35 \mathrm{~cm} \times 28 \mathrm{~cm}$ yang diisi air laut dengan sistem resirkulasi selama 70 hari. Ikan diberi pakan uji sesuai perlakuan tiga kali sehari sampai kenyang. Hasil penelitian menunjukkan penambahan $\mathrm{AH}$ baik jenis AHA maupun AHS pada pakan dapat menurunkan akumulasi $\mathrm{Cd}$ dalam daging, ginjal, dan hati; kedua jenis AH tersebut mampu mengeliminasi $\mathrm{Cd}$ di dalam daging ikan. Pada dosis $1.600 \mathrm{mg}^{\mathrm{kg}} \mathrm{kg}^{-1} \mathrm{kedua}$ jenis $\mathrm{AH}$ tersebut mampu meningkatkan performa pertumbuhan dan kelangsungan hidup ikan, namun pada dosis AHA $>1.600$ mg. kg-1 pertumbuhannya relatif menurun. Pola respons pertumbuhan ikan bersesuaian dengan parameter hematologi, enzim pencernaan, dan status antioksidan di hati ikan. Kesimpulan penelitian ini, penambahan asam humat pada dosis yang sama (1.600 mg. $\left.\mathrm{kg}^{-1}\right)$ pada pakan, AHS lebih efisien dibandingkan AHA dalam hal meningkatkan pertumbuhan. Penambahan AH dari jenis asam humat alami dan sintetik dalam pakan uji dapat meningkatkan status kesehatan dan mengeliminasi Cd di dalam daging ikan. Penambahan AHA pada dosis tinggi pada pakan memberikan respons negatif terhadap status kesehatan, kelangsungan hidup, dan kinerja pertumbuhan ikan kakap putih.
\end{abstract}

KATA KUNCl: asam humat; kakap putih Lates calcarifer; kerang hijau Perna viridis; logam berat Cd; pakan; pertumbuhan

ABSTRACT: The effects of humic acid addition in reducing cadmium (Cd) concentration in green mussel used for feed and improving the health statusand growth performance of Asian seabass, Lates calcalifer. By: Rasidi, Dedi Jusadi, Mia Setiawati, Munti Yuhana, Muhammad Zairin Jr., and Ketut Sugama

Humic acids (HAs) are available in natural and synthetic forms. HA has potential applications in aquaculture, yet its effectiveness as a feed additive in Asian seabass, Lates calcarifer has not well studied. The purpose of this study was to asses the effectiveness of the addition of natural and synthetic humic acids to reduce cadmium (Cd) concentration in green mussels Perna viridis used for Asian seabass feed and evaluate the fish health status and growth performance. The experiment was designed using a completely randomized design (CRD) with five treatments and three replications. Five test feeds containing different levels of humic acid, i.e., $0 ; 1,600 ; 10,000$; and 20,000 mg natural humic acid kg ${ }^{1}$ feed. As a comparison, a test feed was added with $1,600 \mathrm{mg}$ synthetic humic acid $\mathrm{kg}^{-1}$ feed. Asian seabass juveniles

\footnotetext{
* Korespondensi: Departemen Budidaya, Fakultas Kelautan dan Perikanan, Institut Pertanian Bogor. Kampus IPB Darmaga, Jalan Agatis, Babakan, Kec. Dramaga, Kota Bogor, Jawa Barat 16128. Tel. + 622518622909

E-mail: siflounder@gmail.com; dedidj@ipb.ac.id
} 
$(4.18 \pm 0.25 \mathrm{~g})$ were cultivated in seawater aquarium equipped with a recirculation system for 70 days. Fifteen aquaria of $80 \mathrm{~cm} \times 35 \mathrm{~cm} \times 28 \mathrm{~cm}$ were used as the culture tanks. The fish were fed with the experimental diet three times every day at the satiation level. The results showed that the addition of both $\mathrm{HAs}$ (natural, AHA and synthetic, AHS) in feed could reduce Cd level in the fish meat, kidneys, and liver. At a dose of $1,600 \mathrm{mg} \cdot \mathrm{kg}^{-1}$, both HAs were able to improve the growth performance and survival of fish. However, at doses $>1,600 \mathrm{mg}^{\mathrm{kg}}{ }^{-1}$, fish growth was relatively suppressed. Fish growth response patterns were concomitant with the hematological parameters, digestive enzymes, and antioxidant status in fish liver. This study concludes that the addition of AHS at $1,600 \mathrm{mg} \cdot \mathrm{kg}^{-1}$ feed is more efficient in terms of increasing growth compared with the same AHA level. The addition of HA, either natural and synthetic humic acid in the feed, can improvethe health status of Asian seabass and eliminate $C d$ in the fish meat. The addition of AHA at higher doses (> 1,600 mg. $\mathrm{kg}^{-1}$ feed) might cause a negative response to health status, survival, and growth performance of Asian seabass.

\section{KEYWORDS: Asian seabass Lates calcarifer; feed; green mussel, Perna viridis; growth performance; humic acid}

\section{PENDAHULUAN}

Ikan kakap putih Lates calcarifer merupakan salah satu komoditas budidaya laut yang prospektif dikembangkan. Produksi budidaya ikan kakap putih di Indonesia rata-rata selama tahun 2012-2016 sebesar 6.097 ton atau $10,70 \%$ produksi dunia sebesar 56.933 ton (FAO, 2019). Kementerian Kelautan dan Perikanan (KKP) menargetkan peningkatan produksi budidaya ikan kakap putih pada tahun 2019 sebesar 6.471 ton (DJPB, 2016). Peningkatan target produksi tersebut akan meningkatkan kebutuhan pakan dan bahan bakunya. Bahan baku utama pakan khususnya tepung ikan yang selama ini masih tergantung impor akan berdampak pada kenaikan harga pakan.

Ketergantungan terhadap penggunaan tepung ikan perlu dikurangi salah satunya dengan memanfaatkan kekerangan sebagai bahan baku pakan untuk mensubstitusi tepung ikan. Berdasarkan penelitian terdahulu, kerang hijau Perna viridistelah dimanfaatkan sebagai bahan baku pakan untuk beberapa jenis ikan (Mohanta et al., 2013; Vidacovic, 2015), yang mengindikasikan kerang hijau dapat dijadikan alternatif sumber protein pakan ikan. Namun sesuai dengan sifat hidupnya sebagai nonselektif filter feeder, kekerangan seringkali mengandung logam berat salah satunya kadmium (Cd) (Riani et al., 2018).

Kadmium berasal dari industri baterai, pelapisan logam dan plastik yang masuk ke perairan, melalui rantai makanan akan terakumulasi dalam tubuh kekerangan. Berdasarkan penelitian pendahuluan diketahui kandungan $\mathrm{Cd}$ pada daging kerang hijau sebesar 0,08 $\mathrm{mg} \mathrm{kg}^{-1}$. Batas baku mutu $\mathrm{Cd}$ dalam produk kekerangan menurut standar FAO $<0,05$ mg. kg ${ }^{-1}$ (Bosch et al., 2016). Kandungan Cd pada kerang hijau tersebut telah melewati baku mutu, sehingga akan bersifat toksik jika dikonsumsi baik oleh manusia maupun hewan. $\mathrm{Cd}$ diketahui dapat menyebabkan osteoporosis, anemia, dan gangguan saluran ginjal (Jaishankar et al., 2014).
Salah satu alternatif pemanfaatan kerang hijau yang mengandung logam berat adalah sebagai bahan baku pakan ikan. Jika kerang hijau tersebut dapat dimanfaatkan sebagai bahan baku pakan, maka diharapkan permintaan kerang hijau akan semakin meningkat pada masa depan. Meningkatnya permintaan kerang hijau diperlukan peningkatan produksinya, dengan potensi lahan yang masih terbuka luas untuk pengembangan budidaya kerang hijau sehingga produksinya dapat ditingkatkan (Rajagopal et al., 2006; Radiarta et al., 2011). Pengembangan budidaya kerang hijau mempunyai manfaat ekologis sebagai biofilter perairan yang tercemar. Selain itu, teknologi budidayanya juga relatif sederhana dan tanpa input pakan sehingga lebih ekonomis. Selanjutnya dampak yang diharapkan, keberlanjutan usaha budidaya kerang hijau dapat berlanjut. Solusi atas pemanfaatan kerang hijau yang mengandung logam berat diyakini sebagai salah satu jalan untuk meningkatkan produksi kerang hijau di Indonesia.

Pemanfaatan kerang hijau yang mengandung $\mathrm{Cd}$ sebagai bahan baku pakan memungkinkan $\mathrm{Cd}$ akan terakumulasi dalam tubuh ikan dan dapat bersifat toksik. Oleh karena itu, diperlukan upaya untuk mereduksi toksisitas $\mathrm{Cd}$ tersebut. Salah satu alternatifnya dengan menambahkan asam humat (AH) dalam pakan ikan. Asam humat memiliki gugus fungsional dan aromatik yang berpotensi untuk membentuk ikatan kompleks dengan logam berat sehingga digunakan sebagai agen chelator logam berat (Klocking, 1992). Berdasarkan proses pembuatannya, AH terdiri atas asam humat alami (AHA) dan sintetik (AHS). AHS telah digunakan untuk mengeliminasi $\mathrm{Cd}$ pada ikan nila (Osman et al., 2009). Penambahan AHA pada pakan juga telah dilakukan untuk mengeliminasi logam berat Pb pada ikan nila (Marlinda, 2016; Robin et al., 2017). Selain sebagai chelator logam berat, AH juga bermanfaat dapat meningkatkan status kesehatan saluran pencernaan, meningkatkan gambaran darah, dan pertumbuhan (Yoruk et al., 2004; Yýlmaz et al., 
2018). Berdasarkan penelitian terdahulu penambahan asam fulvat sintetik pada pakan dengan dosis optimal sebesar $1,5 \% 2 \%$ dapat meningkatkan pertumbuhan ikan loach, Paramisgurnus dabryanus (Gao et al., 2017).

Berdasarkan penelitian terdahulu yang menggunakan AHA (kadar AH sebesar 4,92\%), diperoleh dosis penambahan AHA sebesar 1.600 mg. $\mathrm{kg}^{-1}$ pakan yang menghasilkan performa pertumbuhan terbaik, namun dosis tersebut belum mampu mengeliminasi $\mathrm{Cd}$ dalam daging ikan kakap putih (Rasidi et al., 2019). Oleh karena itu, diperlukan penelitian Ianjutan penambahan AHA dengan dosis yang semakin tinggi. Peningkatan dosis AHA yang semakin meningkat diharapkan dapat diperoleh hasil yang efektif dibandingkan dengan menggunakan AHS. Tujuan penelitian ini untuk mengetahui efektivitas penambahan $\mathrm{AH}$ pada pakan yang mengandung $\mathrm{Cd}$ dari kerang hijau Perna viridis terhadap status kesehatan dan pertumbuhan ikan kakap putih, Lates calcarifer.

\section{BAHAN DAN METODE}

Penelitian ini dilakukan dari bulan Desember 2018 sampai dengan April 2019 di Laboratorium Riset Ikan Hias Laut, Balai Riset Budidaya Ikan Hias Depok. Analisis sampel dilakukan di beberapa laboratorium di lingkungan Institut Pertanian Bogor (IPB), Bogor; Instalasi Riset Kesehatan Ikan, Depok; dan Laboratorium Pusat Kajian Stres Oksidatif dan Hipoksia, Fakultas Kedokteran Univeritas Indonesia (FKUI), Salemba, Jakarta.

Asam humat (AH) yang digunakan terdiri atas dua jenis yaitu asam humat alami (AHA) (Humakos) dan asam humat sintetik (AHS) (Sigma Aldrich) sebagai pembanding. Asam humat alami yang digunakan mempunyai kadar asam humat sebesar 4,92\%(Rasidi et al., 2019), sedangkan AHS (Sigma Aldrich) dengan tingkat kemurnian $97 \%$ (sesuai label produk). Perco baan dirancang dengan menggunakan rancangan acak lengkap (RAL) dengan lima perlakuan dengan tiga ulangan. Masing-masing perlakuan terdiri atas: pakan tanpa tambahan $\mathrm{AH}$ sebagai pakan kontrol (0 $\mathrm{AH})$, pakan dengan penambahan asam humat sintetik sebesar 1.600 mg.kg-1 pakan (1.600 AHS), pakan dengan penambahan asam humat alami (AHA) masingmasing sebesar 1.600; 10.000; dan 20.000 mg. $\mathrm{kg}^{-1}$ pakan (1.600 AHA; $10.000 \mathrm{AHA}$; dan 20.000 AHA).

Bahan baku utama pakan berupa daging kerang hijau diperoleh dari Cilincing, Jakarta Utara. Daging kerang dikeringkan dan dibuat menjadi tepung. Tepung daging kerang hijau dan bahan baku pakan lainnya kemudian dianalisis proksimat, selanjutnya dilakukan formulasi pakan sesuai dengan perlakuan masing-masing dengan dosis penambahan AH yang berbeda (Tabel 1). Pakan dan ikan uji kemudian dianalisis proksimat menggunakan metode standar (AOAC, 1984); selain itu, dianalisis kandungan logam berat $\mathrm{Cd}$ menggunakan metode atomic absorption spectrofotometry (AAS). Analisis kandungan asam humat pada pakan uji dilakukan menggunakan spektrofotometri di Pusat Litbang Bioindustri, Bogor.

Ikan uji berupa benih ikan kakap putih (bobot ratarata awal 4,18 $\pm 0.25 \mathrm{~g}$ ) diperoleh dari Balai Budidaya Laut (BBL) Lampung. Ikan uji diaklimatisasi terlebih dahulu sebelum diberi perlakuan pada akuarium selama 15 hari di Balai Riset Ikan Hias, Depok. Selanjutnya dilakukan pemuasaan selama 24 jam. Ikan diseleksi, ditimbang, dan dimasukkan ke dalam akuarium berukuran $80 \mathrm{~cm} \times 35 \mathrm{~cm} \times 28 \mathrm{~cm}$ berisi air laut 61,6 L. Air laut diperoleh dari Seaworld Ancol, Jakarta. Penebaran ikan dilakukan sebanyak 25 ekor/akuarium. Ikan dipelihara selama 70 hari dengan pemberian pakan uji diberikan sampai kenyang (at satiation). Frekuensi pemberian pakan sebanyak tiga kali sehari pada pukul 08.00, 12.00, dan 16.00 WIB. Penyiponan dilakukan setiap hari, kemudian dilakukan pergantian air sebanyak $30 \%$ setiap dua hari. Penambahan air pada tandon resirkulasi dilakukan setelah penyiponan.

Pengukuran kualitas air secara in situ menggunakan alat multiparameter water quality merk YSI 556. Hasil pengukuran kualitas air untuk suhu berkisar antara $28,22^{\circ} \mathrm{C}-29,30^{\circ} \mathrm{C}$; oksigen terlarut berkisar antara $5,42-$ $6,29 \mathrm{mg}^{-\mathrm{L}^{-1}}$; pH berkisar antara 7,74-8,35; salinitas berkisar antara 26,98-27,70 mg..-1. Kadar amonia berkisar antara 0,034-0,210 mg. $\mathrm{L}^{-1}$, nitrit berkisar antara 0,045-0,370 mg. $\mathrm{L}^{-1}$; nitrat berkisar antara 2,45$3,10 \mathrm{mg} \cdot \mathrm{L}^{-1} ;$ logam berat $\mathrm{Cd}$ berkisar antara $0,002-0,004$ $\mathrm{mg} \cdot \mathrm{L}^{-1}$.

Pada awal dan akhir pemeliharaan dilakukan penimbangan bobot ikan untuk mengetahui pertumbuhannya. Jumlah pakan yang dihabiskan dicatat untuk mengetahui tingkat konsumsi pakan, yang berguna untuk menghitung konversi pakan, serta retensi protein. Setelah penimbangan selesai, diambil lima ekor ikan dari setiap akuarium untuk keperluan analisis lebih lanjut di laboratorium. Parameter yang diamati meliputi kelangsungan hidup, bobot ikan, laju pertumbuhan spesifik, jumlah konsumsi pakan, retensi protein, dan konversi pakan. Analisis di laboratorium meliputi proksimat pakan dan ikan, logam Cd di pakan dan ikan, gambaran darah ( $\mathrm{Hb}, \mathrm{Hc}$, dan sel darah merah $(\mathrm{SDM}))$, enzim pencernaan dan enzim oksidatif.

Parameter hematologis yang diukur meliputi hemoglobin $(\mathrm{Hb})$, hematokrit $(\mathrm{Hc})$, dan sel darah merah (SDM). Data hematologi tersebut kemudian dijadikan dasar dalam perhitungan mean corpuscular hemoglobin (MCH), berdasarkan Blaxhall \& Daisley (1973). 
Tabel 1. Komposisi, proksimat, logam berat $\mathrm{Cd}$, dan kadar asam humat pada pakan untuk uji pertumbuhan ikan dengan perbedaan penambahan dosis asam humat $(0 ; 1.600 ; 10.000$; dan $\left.20.000 \mathrm{mg}^{\mathrm{kg}} \mathrm{kg}^{-1}\right)$

Table 1. Ingredient, proximate, heavy metal $\mathrm{Cd}$, and humic acid content in feed for fish growth test with additional different dosage of humic acid $\left(0 ; 1,600 ; 10,000\right.$; and $\left.20,000 \mathrm{mg}^{\mathrm{kg}} \mathrm{kg}^{-1}\right)$

\begin{tabular}{|c|c|c|c|c|c|}
\hline \multirow{2}{*}{$\begin{array}{l}\text { Bahan } \\
\text { Ingredients } \\
\left(\mathbf{g ~ k g}^{-1}\right)\end{array}$} & \multicolumn{5}{|c|}{ Penambahan dosis asam humat (Dosage humic acid addition ) $\left(\mathrm{mg} \mathrm{kg}^{-1}\right)$} \\
\hline & $\begin{array}{c}\text { O HA } \\
\text { (kontrol/control) }\end{array}$ & $\begin{array}{l}1.600 \text { AHS } \\
1,600 \text { AHS }\end{array}$ & $\begin{array}{l}1.600 \text { AHA } \\
1,600 \text { AHA }\end{array}$ & $\begin{array}{l}10.000 \text { AHA } \\
10,000 \text { AHA }\end{array}$ & $\begin{array}{l}20.000 \text { AHA } \\
20,000 \text { AHA }\end{array}$ \\
\hline Tepung ikan (Fish meal) & 260 & 260 & 260 & 260 & 260 \\
\hline $\begin{array}{l}\text { Tepung kedelai } \\
\text { Soy bean meal (SBM) }\end{array}$ & 115 & 115 & 115 & 115 & 115 \\
\hline $\begin{array}{l}\text { Tepung daging dan tulang } \\
\text { Meat and bone meal (M BM) }\end{array}$ & 115 & 115 & 115 & 115 & 115 \\
\hline Tepung terigu (Wheat flour ) & 130 & 128.4 & 128.4 & 120 & 110 \\
\hline $\begin{array}{l}\text { Tepung kerang hijau } \\
\text { Green mussel meal (GSM) }\end{array}$ & 350 & 350 & 350 & 350 & 350 \\
\hline M inyak ikan (fish oil) & 10 & 10 & 10 & 10 & 10 \\
\hline $\begin{array}{l}\text { Campuran mineral } \\
\text { Mineral mix }\end{array}$ & 5 & 5 & 5 & 5 & 5 \\
\hline $\begin{array}{l}\text { Campuran vitamin } \\
\text { Vitamin mix }\end{array}$ & 10 & 10 & 10 & 10 & 10 \\
\hline Binder & 5 & 5 & 5 & 5 & 5 \\
\hline $\begin{array}{l}\text { Asam humat sintetik (AHS) } \\
\text { Synthetic humic acid }\end{array}$ & 0 & 1.6 & 0 & 0 & 0 \\
\hline $\begin{array}{l}\text { Asam humat al ami (AHA) } \\
\text { Natural humic acid }\end{array}$ & 0 & 0 & 1.6 & 10 & 20 \\
\hline Jumlah & 1,000 & 1,000 & 1,000 & 1,000 & 1,000 \\
\hline \multicolumn{6}{|c|}{ Komposisi proksimat pakan (Proximate composition) } \\
\hline $\begin{array}{l}\text { Protein kasar } \\
\text { Crude protein }(\%)\end{array}$ & 48.52 & 47.07 & 47.8 & 47.69 & 48.69 \\
\hline Lemak kasar (Crude lipid) ( $\%$ & 6.22 & 6.14 & 6.11 & 6.22 & 6.36 \\
\hline $\begin{array}{l}\text { Karbohidrat } \\
\text { Carbohydrat }(\%)\end{array}$ & 19.66 & 19.26 & 21.03 & 23.46 & 23.33 \\
\hline Kadar abu (Ash content) $(\%)$ & 13.54 & 13.32 & 13.18 & 13.33 & 13.34 \\
\hline $\begin{array}{l}\text { Kadar air } \\
\text { Moisture content }(\%)\end{array}$ & 11.23 & 13.18 & 10,135 & 7.86 & 7.26 \\
\hline $\begin{array}{l}\text { Gross energi (kkal/100 g)* } \\
\text { Gross energy (kcal/100 g) }\end{array}$ & 413.17 & 402.60 & 413.70 & 424.11 & 430.54 \\
\hline $\begin{array}{l}\text { Energi (kkal/\%protein) } \\
\text { Protein (kcal/\%protein) }\end{array}$ & 8.52 & 8.55 & 8.65 & 8.89 & 8.84 \\
\hline \multicolumn{6}{|l|}{ Hasil analisis (Result analysis) } \\
\hline $\begin{array}{l}\text { ** Logam berat } \mathrm{Cd} \\
\text { Heavy metal } \mathrm{Cd}\left(\mathrm{mg} \cdot \mathrm{kg}^{-1}\right)\end{array}$ & 0.10 & 0.11 & 0.12 & 0.13 & 0.13 \\
\hline Asam humat $\left(\mathrm{mg}^{\mathrm{kg}} \mathrm{kg}^{-1}\right)$ & $\mathrm{ttd}$ & 0.37 & 0.023 & 0.14 & 0.30 \\
\hline
\end{tabular}

Keterangan (Note):

* Gross energy (GE) dihitung berdasarkan konversi NRC (2002) yaitu 5,64 kkal/g protein; 9,44 kkal/g lemak; dan 4,11 kkal/g BETN (Gross energy (GE) calculated based in conversion NRC (2002): $5.64 \mathrm{kcal} / \mathrm{g}$; $9.44 \mathrm{kcal} / \mathrm{g}$ lipid; and $4.11 \mathrm{kcal} / \mathrm{g} \mathrm{NFE}$ )

*) Analisis Cd menggunakan metode atomic absorption spectrofotometry (AAS) (Analysis Cd used atomic absorption spectrofotometry (AAS) method) 
Pengambilan sampel dari saluran pencernaan untuk analisis kelimpahan total dan jenis bakteri, dan enzim pencernaan. Kelimpahan bakteri total dihitung dengan menggunakan metode total plate count (TPC) pada media TSA yang ditambahkan $\mathrm{NaCl}$ (SNI 01-2332.32006). Identifikasi spesies bakteri dilakukan secara biokimiawi (Benson, 2001). Pengukuran aktivitas enzim protease diukur mengikuti prosedur menurut Walter (1984), aktivitas enzim amilase (Bernfeld, 1955), dan aktivitas enzim lipase (Linfield et al., 1984). Pengukuran enzim oksidatif dan antioksidan meliputi kadar enzim malonealdehyde (MDA), katalase (CAT), superoxida dismutase (SOD), dan glutathione peroxidase (GPX) pada organ hati ikan kakap putih. Pengukuran MDA dilakukan dengan menggunakan metode uji asam tiobarbiturat (TBA) secara spektrofotometri (Wills, 1987). Aktivitas enzim SOD dan GPx diukur menggunakan metode spektofotometri dengan berpedoman pada standar operasional prosedur dari kit komersial (Randox). Pemeriksaan aktivitas enzim katalase dilakukan dengan spektrofotometri mengacu pada Muradian et al. (2002).

\section{Analisis Data}

Data kelangsungan hidup, bobot ikan, laju pertumbuhan spesifik, jumlah konsumsi pakan, retensi protein dan konversi pakan, enzim pencernaan dan enzim oksidatif dianalisis menggunakan uji sidik ragam dengan taraf kepercayaan 95\% Jika ada perbedaan nyata dilakukan uji lanjut dengan menggunakan uji Duncan menggunakan program IBM SPSS versi 21.0. Kelimpahan bakteri dan gambaran darah $(\mathrm{Hb}, \mathrm{Hc}$, dan SDM) dianalisis secara deskriptif.

\section{HASIL DAN BAHASAN}

Ikan yang diberi pakan dengan penambahan asam humat $(\mathrm{AH})$ dengan dosis yang berbeda berpengaruh nyata terhadap kinerja pertumbuhan dan kelangsungan hidup ikan jika dibandingkan dengan ikan kontrol selama 70 hari pemeliharaan (Tabel 2).

Kinerja pertumbuhan pada ikan yang diberi pakan dengan penambahan $\mathrm{AH}$ meningkat dibandingkan dengan ikan kontrol, hal ini menunjukkan bahwa penambahan $\mathrm{AH}$ dalam pakan dapat meningkatkan pemanfaatan nutrien pakan. Kinerja pertumbuhan dan tingkat pemanfaatan pakan yang meningkat terkait dengan aktivitas enzim pencernaan, retensi nutrien pakan, dan konversi pakan. Berdasarkan jenis AH yang ditambahkan, AHA dan AHS pada dosis yang sama sebesar $1.600 \mathrm{mg} \mathrm{kg}^{-1}$ dalam pakan memberikan respons positif terhadap pertumbuhan. Hasil ini menunjukkan bahwa sesuai dengan penelitian sebelumnya penambahan dosis AHA sebesar 1.600 mg. $\mathrm{kg}^{-1}$ dalam pakan menghasilkan kinerja pertumbuhan yang terbaik pada ikan kakap putih (Rasidi et al., 2019). Namun demikian jika dibandingkan dengan jenis $\mathrm{AH}$ yang ditambahkan pada dosis yang sama penambahan AHS pada pakan

Tabel 2. Bobot awal $\left(\mathrm{W}_{0}\right)$, bo bot akhir $\left(\mathrm{W}_{\mathrm{t}}\right)$, jumlah konsumsi pakan (JKP), retensi protein (RP), kelangsungan hidup (KH), laju pertumbuhan spesifik (LPS), dan rasio konversi pakan (RKP) dengan perbedaan penambahan dosis asam humat (0; 1.600; 10.000; dan 20.000 mg.kg-1 pakan)

Table 2. Initial weight $\left(\mathrm{W}_{0}\right)$, final weight $\left(\mathrm{W}_{\mathrm{t}}\right)$, feed consumption (AFC), protein retention (RP), survival rate $(S R)$, specific growth rate (SGR), and feed conversion ratio (FCR) with addition of different dosages of humic acid $\left(0 ; 1,600 ; 10,000\right.$; and 20,000 $\mathrm{mg} \mathrm{kg}^{-1}$ feed)

\begin{tabular}{|c|c|c|c|c|c|}
\hline \multirow{2}{*}{$\begin{array}{l}\text { Parameter } \\
\text { Parameters }\end{array}$} & \multicolumn{5}{|c|}{ Penambahan dosis AH/HA dosage addition (mg. $\mathrm{kg}^{-1}$ ) } \\
\hline & $\begin{array}{c}\text { O HA } \\
\text { (kontrol/control) }\end{array}$ & $\begin{array}{l}1.600 \text { AHS } \\
1.600 \text { AHS }\end{array}$ & $\begin{array}{l}1.600 \mathrm{AHA} \\
1.600 \mathrm{AHA}\end{array}$ & $\begin{array}{l}10.000 \text { AHA } \\
10.000 \text { AHA }\end{array}$ & $\begin{array}{l}20.000 \text { AHA } \\
20.000 \text { AHA }\end{array}$ \\
\hline Bobot awal (Initial weight) (g) & $4.10 \pm 0.24^{a}$ & $4.09 \pm 0.34^{\mathrm{a}}$ & $4.06 \pm 0.04^{a}$ & $4.06 \pm 0.12^{a}$ & $4.01 \pm 0.02^{a}$ \\
\hline Bobot akhir (Final weight) (g) & $7.63 \pm 0.39^{a}$ & $10.90 \pm 0.69^{b}$ & $10.05 \pm 0.14^{b}$ & $8.77 \pm 0.59^{b}$ & $7.77 \pm 0.19^{a}$ \\
\hline $\begin{array}{l}\text { Jumlah konsumsi pakan (g.ikan }{ }^{-1} \text { ) } \\
\text { Feed consumption (g.fish }{ }^{-1} \text { ) }\end{array}$ & $13.15 \pm 0.85^{c}$ & $11.18 \pm 0.39^{b c}$ & $12.75 \pm 0.20^{\mathrm{ab}}$ & $12.21 \pm 1.26^{\mathrm{ab}}$ & $10.59 \pm 0.96^{b}$ \\
\hline Retensi pakan (Protein retention) ( $\%$ & $7.13 \pm 2.10^{\mathrm{a}}$ & $17.61 \pm 1.02^{c}$ & $14.87 \pm 2.91^{b c}$ & $12.87 \pm 1.63^{b}$ & $11.94 \pm 1.36^{b}$ \\
\hline Sintasan (Survival rate) $(\%)$ & $76.00 \pm 4.00^{\mathrm{a}}$ & $94.67 \pm 4.61^{c}$ & $86.67 \pm 2.31^{b c}$ & $78.67 \pm 6.11^{a b}$ & $77.33 \pm 6.11^{\mathrm{a}}$ \\
\hline $\begin{array}{l}\text { Laju pertumbuhan spesifik }\left(\% \text { hari }^{-1}\right) \\
\text { Specific growth rate }\left(\% \text { days }^{-1}\right)\end{array}$ & $0.76 \pm 0.02^{\mathrm{a}}$ & $1.35 \pm 0.06^{\mathrm{e}}$ & $1.29 \pm 0.12^{d}$ & $1.13 \pm 0.02^{c}$ & $0.95 \pm 0.04^{b}$ \\
\hline $\begin{array}{l}\text { Rasio konversi pakan } \\
\text { Feed conversion ratio }\end{array}$ & $3.89 \pm 1.02^{a}$ & $1.65 \pm 0.10^{c}$ & $2.34 \pm 0.07^{b c}$ & $2.60 \pm 0.30^{b}$ & $2.82 \pm 0.50^{b}$ \\
\hline
\end{tabular}

Keterangan: Angka-angka pada baris yang sama yang diikuti huruf yang berbeda menunjukkan hasil yang berbeda nyata $(\mathrm{P}<0,05)$

Note: $\quad$ Number in the same row follows by different characters meaning significantly different $(P<0.05)$ 
mengakibatkan pertumbuhan ikan lebih tinggi dibandingkan ikan yang diberi pakan dengan penambahan AHA. Perbedaan respons pertumbuhan tersebut dalam dalam penelitian ini dapat dilihat dari ikan yang mengonsumsi pakan 1.600 AHS bersesuaian dengan nilai-nilai parameter yang diamati yang lebih baik dibandingkan dengan 1.600 AHA (Tabel 2). Hal ini diduga disebabkan terkait spesifikasi gugus fungsional dan kemampuan masing-masing jenis $\mathrm{AH}$ dalam fungsinya sebagai chelator logam berat, dan meningkatkan pemanfaatan nutrien pakan. Respons positif juga ditunjukkan pada penelitian terdahulu yang menggunakan AHS secara signifikan meningkatkan pertambahan bobot ikan swordtails (Xiphophorus helleri) (Meinelt et al., 2008).

Pada penelitian ini, meningkatnya penambahan $\mathrm{AH}$ pada pakan uji berkorelasi positif dengan kelimpahan mikrobiota di usus ikan (Tabel 3). Menurut Ringo et al. (2006), jenis pakan yang masuk dalam sistem pencernaan akan memengaruhi kelimpahan dan jenis mikrobiota dalam saluran pencernaan. Penambahan $\mathrm{AH}$ memberikan keuntungan secara tidak langsung sebagai prebiotik, karena mikrobiota di dalam saluran pencernaan dapat memanfaatkan asam humat sebagai sumber energi seperti karbon, N, dan P (Stevenson, 1994). Selanjutnya Islam et al. (2005) menyatakan bahwa asam humat mampu menstabilkan mikrobiota di usus. Berdasarkan Tabel 3 dapat diketahui mikrobiota yang dominan diperoleh tiga jenis bakteri. Ketiga jenis bakteri dominan tersebut berpotensi sebagai probiotik. Menurut penelitian terdahulu, Ba- cillus $\mathrm{sp}$. berperan dalam proses pencernaan yang dapat menghasilkan enzim pencernaan yang meningkatnya retensi protein dan sistem imun sehingga berdampak pada pertumbuhan ikan yang semakin meningkat (Widanarni et al., 2015).

Kelimpahan dan jenis bakteri dominan yang ditemukan di usus ikan uji diduga berdampak pada aktivitas enzim pencernaan. Aktivitas enzim pencernaan berbeda nyata antara ikan yang diberi perlakuan penambahan AH dan ikan kontrol, namun tidak berbeda nyata antar ikan yang diberi pakan dengan penambahan AHA maupun AHS $(\mathrm{P}>0,05)$ (Tabel 4). Meningkatnya kelimpahan mikrobiota ini diduga berdampak pada meningkatnya enzim pencernaan di usus ikan yang merupakan indikator kemampuan dalam mencerna dan memanfaatkan pakan yang diberikan. Pakan dengan penambahan AH dapat dimanfaatkan lebih baik sehingga lebih efisien dibandingkan pakan kontrol. Tingkat pemanfaatan pakan dapat dilihat dari nilai konversi pakan yang semakin menurun yang menunjukkan pakan yang dikonsumsi lebih efisien dimanfaatkan untuk pertumbuhan. Hasil ini sesuai dengan penelitian sebelumnya pada ikan loach yang diberi pakan dengan penambahan asam fulvat dalam pakan uji mampu memperbaiki pemanfaatan pakan sehinggga pertumbuhan ikan dan efisiensi pakan meningkat (Gao et al., 2017).

Penambahan $\mathrm{AH}$ baik jenis alami maupun sintetis dalam pakan uji mampu menurunkan $\mathrm{Cd}$ di dalam organ hati dan ginjal; $\mathrm{Cd}$ dalam daging ikan tidak

Tabel 3. Kelimpahan total mikrobiota di usus ikan dan identifikasi bakteri, enzim pencernaan dari usus ikan yang diberi pakan dengan perbedaan penambahan dosis asam humat $(0 ; 1.600$; 10.000; dan $20.000 \mathrm{mg} \mathrm{kg}^{-1}$ pakan)

Tabel 3. Total plate count of fish intestine microbiota and identification of species bacteria in fish intestine, enzyim digestion, with additionc of different dosages of humic acid $(0 ; 1,600 ; 10,000 ;$ and 20,000 $\mathrm{mg} . \mathrm{kg}^{-1}$ feed)

\begin{tabular}{|c|c|c|c|c|c|}
\hline \multirow{2}{*}{$\begin{array}{l}\text { Parameter } \\
\text { Parameters }\end{array}$} & \multicolumn{5}{|c|}{ Penambahan AH (HA addition ) (mg kg $\left.{ }^{-1}\right)$} \\
\hline & $\begin{array}{c}\text { O HA } \\
\text { (kontrol/control ) }\end{array}$ & $\begin{array}{l}1.600 \text { AHS } \\
1.600 \text { AHS }\end{array}$ & $\begin{array}{l}1.600 \text { AHA } \\
1.600 \text { AHA }\end{array}$ & $\begin{array}{l}10.000 \text { AHA } \\
10.000 \text { AHA }\end{array}$ & $\begin{array}{l}20.000 \text { AHA } \\
20.000 \text { AHA }\end{array}$ \\
\hline $\begin{array}{l}\text { Kelimpahan total mikrobiota } \\
\text { TPC microbiota ( } \log \text { CFU. } \mathrm{mL}^{-1} \mathrm{~g}^{-1} \text { ) }\end{array}$ & $1.56 \pm 0.43$ & $2.18 \pm 0.44$ & $2.86 \pm 0.12$ & $2.89 \pm 0.32$ & $3.13 \pm 0.33$ \\
\hline $\begin{array}{l}\text { Gram positif/negatif } \\
\text { Gram positive/negative }(\mathrm{gram}+/-)^{1)}\end{array}$ & + & + & + & + & + \\
\hline $\begin{array}{l}\text { Identifikasi spesies bakteri } \\
\text { Identification of species bacteria } \\
\text { Bacillus sp. }\end{array}$ & $\sqrt{ }^{2)}$ & $\sqrt{ }$ & $\sqrt{ }$ & nd & nd \\
\hline Stapyllococcus sp.-1 & $n d^{3)}$ & $\sqrt{ }$ & $\sqrt{ }$ & $\sqrt{ }$ & $\sqrt{ }$ \\
\hline Stapyllococcus sp.-2 & nd & $\sqrt{ }$ & $\sqrt{ }$ & $\sqrt{ }$ & $\sqrt{ }$ \\
\hline
\end{tabular}

Keterangan (Note): $\quad{ }^{1)}$ Bakteri Gram positif/negative (Bacteria Gram positive/negative); $\sqrt{ }=$ dominan (dominant); nd= tidak dominan ditemukan (not dominant found) 
Tabel 4. Aktivitas enzim pencernaan dari usus ikan yang diberi pakan dengan perbedaan penambahan dosis AH selama 70 hari pemeliharaan

Tabel 4. Digestive enzim activity in fish intestine with addition of different dosages of humic acid for 70 days cultivation

\begin{tabular}{|c|c|c|c|c|c|}
\hline \multirow{2}{*}{$\begin{array}{l}\text { Parameter } \\
\text { Parameters }\end{array}$} & \multicolumn{5}{|c|}{ Penambahan AH (HA addition ) ( $\left.\mathrm{mg} \mathrm{kg}^{-1}\right)$} \\
\hline & $\begin{array}{c}0 \mathrm{HA} \\
\text { (kontrol/control) }\end{array}$ & $\begin{array}{l}1.600 \text { AHS } \\
1.600 \text { AHS }\end{array}$ & $\begin{array}{l}1.600 \text { AHA } \\
1.600 \text { AHA }\end{array}$ & $\begin{array}{l}10.000 \text { AHA } \\
10.000 \text { AHA }\end{array}$ & $\begin{array}{l}20.000 \text { AHA } \\
20.000 \text { AHA }\end{array}$ \\
\hline Protease (IU.mL $\left.{ }^{-1}\right)$ & $0.87 \pm 0.0^{\mathrm{a}}$ & $2.45 \pm 0.5^{b}$ & $2.63 \pm 0.38^{b}$ & $2.22 \pm 0.75^{b}$ & $1.75 \pm 0.2^{b}$ \\
\hline Amilase (IU. $\left.\mathrm{mL}^{-1}\right)$ & $0.08 \pm 0.03^{\mathrm{a}}$ & $0.14 \pm 0.01^{b}$ & $0.24 \pm 0.07^{b}$ & $0.31 \pm 0.07^{b}$ & $0.10 \pm 0.01^{\mathrm{a}}$ \\
\hline Lipase $\left(\mu\right.$ mol menit $^{-1} /$ minute $\left.^{-1}\right)$ & $1.32 \pm 0.4^{\mathrm{a}}$ & $3.01 \pm 0.2^{b}$ & $7.03 \pm 0.90^{b}$ & $7.64 \pm 0.1^{b}$ & $7.42 \pm 0.32^{b}$ \\
\hline
\end{tabular}

Keterangan: ${ }^{11}$ Angka-angka pada baris yang sama yang diikuti oleh huruf yang berbeda menunjukkan hasil yang berbeda nyata $(P<0,05)$

The numbers in the same row follows by different characters meaning significantly different $(P<0.05)$

terdeteksi $\left(<0,005 \mathrm{mg} \cdot \mathrm{kg}^{-1}\right)$; sedangkan di dalam daging ikan kontrol masih terdeteksi Cd sebesar 10,11 $\pm 0,40 \mu \mathrm{g} \cdot \mathrm{kg}^{-1}$ (Tabel 4). Dengan demikian penambahan $\mathrm{AH}$ pada pakan uji dapat mencegah akumulasi $\mathrm{Cd}$ di dalam daging ikan sehingga aman dikonsumsi manusia. Hal ini disebabkan AH melalui gugus karboksilat dan fenol yang mampu membentuk ikatan kompleks dengan Cd. Ikatan yang terbentuk lebih stabil sehingga toksisitasnya juga berkurang, dan mengurangi kemungkinan penyerapan logam oleh jaringan sehingga tidak terakumulasi di dalam daging ikan. Selanjutnya $\mathrm{Cd}$ tersebut akan dieksresikan bersama feses (Osman et al., 2009). Hasil penelitian ini sesuai dengan penelitian sebelumnya yang menggunakan $\mathrm{AH}$ dalam air mampu mengeliminasi logam berat Cd (Kamunde \& MacPhail, 2011). Demikian juga pada penambahan $\mathrm{AH}$ melalui pakan dapat mengeliminasi logam berat Pb pada ikan nila (Marlinda, 2016; Robin et al., 2017).

Status kesehatan ikan dapat diamati dari gambaran darahnya meliputi hemoglobin $(\mathrm{Hb})$, hematokrit $(\mathrm{Hc})$, dan jumlah sel darah merah (SDM). Pada penelitian ini ikan yang diberi pakan dengan penambahan $\mathrm{AH}$ mempunyai gambaran darah yang lebih tinggi dibandingkan dengan ikan kontrol (Tabel 6).

Penambahan $\mathrm{AH}$ ada pakan mampu meningkatnya nilai-nilai gambaran darah, hal ini diduga AH berperan dalam menekan toksisitas $\mathrm{Cd}$ sehingga proses pembentukan sel darah merahnya tetap berlangsung (Osman et al., 2009). Hal ini disebabkan penambahan $\mathrm{AH}$ mampu meningkatkan mineral $\mathrm{Fe}$ yang berkontribusi dalam pembentukan SDM sehingga jumlah SDM meningkat. Meningkatnya Fe dalam darah akan berkontribusi dalam meningkatnya jumlah oksigen yang dapat diikat oleh ion $\mathrm{Fe}$, semakin banyak ion Fe dapat mengikat oksigen akan bertambah $\mathrm{Hb}$ dalam SDM. MCH merupakan salah satu indikator untuk mengetahui jumlah $\mathrm{Hb}$ dalam sel darah merah. Pada penelitian ini, nilai hematologi darah ikan masih berada pada kisaran normal ikan kakap putih (Anderson et al., 1996). Hasil penelitian ini sesuai dengan penelitian sebelumnya pada pemanfaatan asam humat

Tabel 5. Kadar Cd di organ (hati, ginjal, dan daging) ikan kakap putih yang diberi pakan dengan perbedaan penambahan dosis AH selama 70 hari pemeliharaan

Tabel 5. Cd content ini fish organ (liver, kidney, and fishmeat) in fish with addition of different dosages of humic acid after 70 days cultivation period

\begin{tabular}{|c|c|c|c|c|c|}
\hline \multirow{3}{*}{$\begin{array}{c}\text { Cd pada organ ikan } \\
\text { CD in fish organs } \\
\left(\mu \mathrm{g} . \mathrm{kg}^{-1}\right)\end{array}$} & \multicolumn{5}{|c|}{$\begin{array}{l}\text { Dosis AH }\left(\mathrm{mg} \mathrm{kg}^{-1}\right) \text { pakan } \\
\text { AH dosage }\left(\mathrm{mg} \mathrm{kg}^{-1}\right) \text { feed }\end{array}$} \\
\hline & \multirow{2}{*}{$\begin{array}{c}\text { O HA } \\
\text { (kontrol/control) }\end{array}$} & \multirow{2}{*}{$\begin{array}{l}1.600 \text { AHS } \\
1.600 \text { AHS }\end{array}$} & \multirow{2}{*}{$\begin{array}{l}1.600 \text { AHA } \\
1.600 \text { AHA }\end{array}$} & \multirow{2}{*}{$\begin{array}{l}10.000 \text { AHA } \\
10.000 \text { AHA }\end{array}$} & \multirow{2}{*}{$\begin{array}{l}20.000 \text { AHA } \\
20.000 \text { AHA }\end{array}$} \\
\hline & & & & & \\
\hline Hati (Liver) & $34.43 \pm 2.42^{c}$ & $11.41 \pm 1.52^{\mathrm{a}}$ & $15.95 \pm 3.19^{b}$ & $11.79 \pm 1.06^{\mathrm{a}}$ & $11.43 \pm 1.63^{\mathrm{a}}$ \\
\hline Ginjal (Kidney) & $10.88 \pm 1.01^{c}$ & $4.67 \pm 0.87^{\mathrm{a}}$ & $6.27 \pm 1.62^{b}$ & $5.23 \pm 0.68^{b}$ & $4.97 \pm 0.44^{a}$ \\
\hline Daging (Meat) & $10.11 \pm 0.40$ & $\mathrm{ttd}^{* *)}$ & $\mathrm{ttd}$ & $\mathrm{ttd}$ & $\mathrm{ttd}$ \\
\hline Keterangan (Note): *) & $\begin{array}{l}\text { Angka-angka pada } \\
\text { hasil yang berbed } \\
\text { characters meaning } \\
\text { ttd = tidak terdet }\end{array}$ & $\begin{array}{l}\text { ris yang sama) } \\
\text { yata }(P<0,05) \\
\text { gnificantly diff } \\
\text { i (not detected }\end{array}$ & $\begin{array}{l}\text { ng diikuti oleh } \\
\text { he numbers in } \\
\text { ant }(P<0.05))\end{array}$ & $\begin{array}{l}\text { uf yang berb } \\
\text { same row follc }\end{array}$ & $\begin{array}{l}\text { menunjukkan } \\
\text { by different }\end{array}$ \\
\hline
\end{tabular}


Tabel 6. Nilai hemoglobin ( $\mathrm{Hb})$, hematokrit $(\mathrm{Hc})$, sel darah merah (SDM), mean corpuscular hemoglobin (MCH), dan Fe dalam darah pada ikan uji dengan perbedaan penambahan dosis asam humat (0; $1.600 ; 10.000$; dan $20.000 \mathrm{mg}^{\mathrm{kg}}{ }^{-1}$ pakan)

Table 6. Value of hemoglobin $(\mathrm{Hb})$, hematokrit $(\mathrm{HC})$, red blood cell (RBC), mean hemoglobin corpuscular $(\mathrm{MCH})$, and Fe in whole fish blood with additional different dosage of humic acid $(0 ; 1,600 ; 10,000$; and 20,000 $\mathrm{mg} \cdot \mathrm{kg}^{-1}$ feed)

\begin{tabular}{|c|c|c|c|c|c|c|}
\hline \multirow{2}{*}{$\begin{array}{l}\text { Parameter } \\
\text { Parameters }\end{array}$} & \multicolumn{5}{|c|}{$\begin{array}{l}\text { Penambahan asam humat }\left(\mathrm{mg}^{-\mathrm{kg}^{-1}} \text { pakan) }\right. \\
\text { Humic acid addition (mg. } \mathrm{kg}^{-1} \text { feed) }\end{array}$} & \multirow{2}{*}{$\begin{array}{c}\text { Kisaran } \\
\text { normal }^{1)} \\
\text { Normal }^{1)} \\
\text { range }^{1)}\end{array}$} \\
\hline & $\begin{array}{c}\text { O HA } \\
\text { (kontrol/control) }\end{array}$ & $\begin{array}{l}1.600 \text { AHS } \\
1.600 \text { AHS }\end{array}$ & $\begin{array}{l}1.600 \mathrm{AHA} \\
1.600 \mathrm{AHA}\end{array}$ & $\begin{array}{l}10.000 \text { AHA } \\
10.000 \text { AHA }\end{array}$ & $\begin{array}{l}20.000 \text { AHA } \\
20.000 \text { AHA }\end{array}$ & \\
\hline Hemoglobin $\left(g \cdot d L^{-1}\right)$ & $4.4-5.6$ & $5.6-6.0$ & $5.2-6.6$ & $5.0-6.8$ & $5.0-6.6$ & $6.0-9.5$ \\
\hline Hematokrit $1 \%$ & $13.1-17$ & $20.8-22.9$ & $21.70-22.9$ & $20.0-20.8$ & $22.0-23.4$ & $26.0-40.0$ \\
\hline $\begin{array}{l}\text { Sel darah merah }\left(\times 10^{6} \text { sel. } \mathrm{mm}^{3}\right) \\
\text { Red blood cell }\left(\times 10^{6} \text { cell. } \mathrm{mm}^{3}\right)\end{array}$ & 1.26-1.97 & 55 & 2 & $1.52-2.23$ & $1.9-2.23$ & -5.20 \\
\hline Mean hemoglobin corpuscular (pg) & $28 . .43-34.92$ & $23.53-26.32$ & $22.51-29.60$ & $27.80-30.91$ & $22.42-34.74$ & $16.7-20.6$ \\
\hline Fe darah (Fe blood) $\left(\mathrm{mg} . \mathrm{L}^{-1}\right)$ & $48.76 \pm 1.63^{\mathrm{a}}$ & $68.32 \pm 1.75^{b}$ & $66.36 \pm 1.66^{b}$ & $72.15 \pm 1.13^{c}$ & $75.66 \pm 1.07^{d}$ & \\
\hline
\end{tabular}

Keterangan: ${ }^{1)}$ Anderson et al. (1996); ${ }^{2)}$ Angka-angka pada baris yang sama yang diikuti oleh huruf yang berbeda menunjukkan hasil yang berbeda nyata $(\mathrm{P}<0,05)$

Note: $\quad$ The numbers in the same row follows by different characters meaning significantly different $(P<0.05)$

mampu meningkatkan gambaran darah pada ikan silver catfish, Rhamdia quelen (Da Costa et al., 2015) dan ikan rainbow trout (Yýlmaz et al., 2018).

Hasil pengukuran parameter uji untuk mengetahui tingkat stres oksidatif meliputi peroksidase lemak Malonaldehyde (MDA) dan enzim antioksidan meliputi katalase (CAT), superoxida dismutase (SOD), dan gluthatione peroxidase (GPx) pada hati ikan kakap putih disajikan pada Tabel 7. Ikan yang diberi pakan dengan penambahan $\mathrm{AH}$ mampu menurunkan stres oksidatif ditandai dengan kadar MDA yang menurun dibandingkan dengan kontrol. Hal ini sesuai dengan menurunnya akumulasi $\mathrm{Cd}$ di hati ikan uji akibat penambahan AH pada pakan (Tabel 5). Peran AH melalui gugus fungsi karboksil yang mengkhelat ion $\mathrm{Cd}$ sehingga toksisitasnya menurun dan tingkat stresnya juga menurun. Namun dengan meningkatnya dosis AHA sampai dengan $20.000 \mathrm{mg}^{\mathrm{kg}} \mathrm{g}^{-1}$ pakan menunjukkan kadar MDA meningkat lagi. Menurut Hseu \& Yang (2002), penambahan AH pada dosis yang berlebih dapat menyebabkan stres oksidatif yaitu tidak seimbangnya produksi oksigen reaktif dan hidrogen peroksida dengan enzim antioksidan dalam sel. Peningkatan peroksidasi lemak disebabkan karena sel kekurangan enzim antioksidan, seperti SOD dan GPx. SOD akan mengonversi oksigen reaktif menjadi $\mathrm{H}_{2} \mathrm{O}_{2}$

Tabel 7. Aktivitas peroksidase lemak, Malonaldehyde (MDA), enzim Katalase (CAT) dan Superoksida Dismutase (SOD), Gluthatione Peroksidase (GPx) di hati ikan kakap putih yang diberi pakan dengan perbedaan dosis dan jenis AH selama 70 hari pemeliharaan.

Table 7. Activity of lipid peroxidase, Malonealdehyde (MDA), enzym Catalase (CAT) and Superoksida Dismutase (SOD), Gluthatione Peroksidase (GPx) from liver fish fed feed with different humic acid addition $\left(0,1600,10000\right.$ and $20000 \mathrm{mg} \mathrm{Kg}^{-1}$ feed $)$

\begin{tabular}{|c|c|c|c|c|c|}
\hline \multirow{2}{*}{$\begin{array}{l}\text { Parameter } \\
\text { Parameters }\end{array}$} & \multicolumn{5}{|c|}{$\begin{array}{c}\text { Dosis AH dalam pakan } \\
\text { AH dosage in feed (mg. } \mathrm{kg}^{-1} \text { ) }\end{array}$} \\
\hline & $\begin{array}{c}\text { O HA } \\
\text { (kontrol/control ) }\end{array}$ & $\begin{array}{l}1.600 \text { AHS } \\
1.600 \text { AHS }\end{array}$ & $\begin{array}{l}1.600 \text { AHA } \\
1.600 \text { AHA }\end{array}$ & $\begin{array}{l}10.000 \text { AHA } \\
10.000 \text { AHA }\end{array}$ & $\begin{array}{l}20.000 \text { AHA } \\
20.000 \text { AHA }\end{array}$ \\
\hline M DA (nmol mL $\left.{ }^{-1}\right)$ & $58.7 \pm 1.08^{c}$ & $28.27 \pm 2.10^{\mathrm{a}}$ & $33.40 \pm 2.56^{b}$ & $56.66 \pm 1.79^{c}$ & $57.32 \pm 1.74^{c}$ \\
\hline $\mathrm{CAT}\left(\mathrm{U} \mathrm{mL}^{-1}\right)$ & $0.08 \pm 0.01^{a}$ & $0.27 \pm 0.02^{\mathrm{a}}$ & $0.29 \pm 0.01^{\mathrm{a}}$ & $0.09 \pm 0.03^{\mathrm{a}}$ & $0.07 \pm 0.03^{\mathrm{a}}$ \\
\hline $\mathrm{SOD}\left(\mathrm{U} \mathrm{mL}^{-1}\right)$ & $43.14 \pm 2.8^{a}$ & $48.01 \pm 1.93^{b}$ & $45.09 \pm 2.18^{b}$ & $53.65 \pm 2.69^{c}$ & $52.91 \pm 1.89^{c}$ \\
\hline GPx $\left(\mathrm{U} \mathrm{mL}^{-1}\right)$ & $0.49 \pm 0.05^{a}$ & $0.80 \pm 0.08^{b}$ & $0.71 \pm 0.17^{b}$ & $0.59 \pm 0.09^{a}$ & $0.56 \pm 0.04^{a}$ \\
\hline
\end{tabular}

Keterangan: ${ }^{1)}$ Angka-angka pada baris yang sama yang diikuti oleh huruf yang berbeda menunjukkan hasil yang berbeda nyata ada taraf uji $95 \%$ (uji selang berganda Duncan)

Note: $\quad$ The numbers in the same row follows by different characters meaning significantly different results at the $95 \%$ test level (Duncan's multiple interval test) 
yang kemudian oleh GPx akan dikonversi menjadi $\mathrm{H}_{2} \mathrm{O}$ (Muradian et al., 2002). Ikan yang mengonsumsi pakan dengan penambahan $\mathrm{AH}$, aktivitas enzim antioksidan (CAT, SOD, dan GPX) lebih tinggi dibandingkan kontrol. $\mathrm{Hal}$ ini mengindikasikan penambahan $\mathrm{AH}$ berperan dalam meningkatkan status antioksidan. Kedua jenis AH ini mempunyai spesifikasi yang berbeda, perbedaan keduanya terletak pada jumlah gugus fungsi dan aromatik. AHS lebih banyak mengandung gugus fenol dibandingkan AHA yang lebih banyak mengandung gugus karboksilatnya (Pompe et al., 1996; Datta et al., 2001). Gugus fungsi yang terdapat pada AHS yang sebagian besar terdiri atas gugus fenolik $(-\mathrm{OH})$, bersifat reaktif terhadap ion logam esensial seperti $\mathrm{Zn}$ dan $\mathrm{Mn}$, kemampuan ini meningkatkan enzim antioksidan yang diperlukan untuk melawan radikal bebas (Zheng \& Shiow 2001).

\section{KESIMPULAN}

Pada dosis asam humat yang sama (1.600 mg. $\mathrm{kg}^{-1}$ pakan), AHS lebih efisien dibandingkan AHA dalam meningkatkan pertumbuhan ikan. Penambahan AH dari jenis asam humat alami dan sintetik dalam pakan uji, keduanya dapat meningkatkan status kesehatan dan mengeliminasi $\mathrm{Cd}$ di dalam daging ikan. Penambahan AHA dosis tinggi pada pakan memberikan respons negatif terhadap status kesehatan, kelangsungan hidup, dan kinerja pertumbuhan ikan kakap putih.

\section{UCAPAN TERIMA KASIH}

Penulis mengucapkan terima kasih kepada Kepala Pusat Pendidikan, Badan Riset dan Sumber Daya Manusia Kelautan dan Perikanan, Kementerian Kelautan dan Perikanan yang telah memberikan beasiwa dan bantuan dana penelitian; Kepala Balai Riset Budidaya Ikan Hias, Depok yang telah memberikan izin dan sarana untuk melakukan penelitian. Teknisi dan laboran yang telah membantu pelaksanaan penelitian ini.

\section{DAFTAR ACUAN}

Anderson, I.G., Schaumuller, L.F., \& Kramer, H.L. (1996). A preliminary study on the hematology of freshwater-reared seabass/barramundi Lates calcarifer. Asian Fisheries Sci., 9, 101-107.

Association of Official Analytical Chemists [AOAC]. (1984). Official methods of analysis. 15th Ed. Helrich, K. (Ed.). Arlington: AOAC.

Benson, H.J. (2001). Benson's microbiological applications: Laboratory manual in general microbiology. 8th Ed. New York: McGraw-Hill, xi + 478 pp.

Blaxhall, P.C. \& Daisley, K.W. (1973). Routine haematological methods for use with fish blood. Journal of Fish Biology, 5(6), 771-781.
Bernfeld, P. (1955). Amylases á and â: M ethod Enzymol., 1, 149-158.

Bosch, A.C., O'Neill, B., Sigge, G.O., Kerwath, S.E., \& Hoffman, L.C. (2016). Heavy metals in marine fish meat and consumer health: A review. J. Sci. Food \& Agric., 96, 32-48.

Da Costa, S.T., Gressler, L.T., Sutili, F.J., Loebens, L., Lazzari, R., \& Baldisserotto, R. (2015). Effect of humic acid on survival, ionoregulation and hematology of the silver catfish, Rhamdia quelen (Siluriformes: Heptapteridae), exposed to different pHs. Zoologia, 32(3), 215-224.

Datta, A., Sanyal, S.K., \& Saha, S. (2001). A study on natural and synthetic humic acids and their complexing ability towards cadmium. Plant and Soil, 235(1), 115-125.

Direktorat Jenderal Perikanan Budidaya [DJPB]. (2016). Data Teknis Direktorat Jenderal Perikanan Budidaya. Jakarta (ID): DJPB.

Food Agriculture Organization of The United Nations [FAO]. (2019). Fishery Statistics. Diunduh pada tanggal 10 Oktober 2019. http://www.fao.org/fishery/statistics/software/fishstatj/en.

Gao, Y., Jie, H., Zhuliu, H., Zhiwei, L., Zhao, B., Yi, M., Jeong-Yeol, L., \& Zhangjie, C. (2017). Effects of fulvic acid on growth performance and intestinal health of juvenile loach Paramisgurnus dabryanus. Fish Shellfish Immunol., 62, 47-56.

Hseu, Y.C. \& Yang, H.L. (2002). The effects of humic acid-arsenate complexes on human red blood cells. Environmental Research, 89(2), 131-137.

Islam, K.M.S., Schuhmacher, A., \& Gropp, J.M. (2005). Humic acid substances in animal agriculture. Pakistan Journal of Nutrition, 4(3), 126-134.

Jaishankar, M., Tseten, T., Anbalagan, N., Mathew, B.B., \& Beeregowda, K.N. (2014). Toxicity, mechanism and health effects of some heavy metals. Interdis Toxic, 7(2), 60-72.

Kamunde, C. \& MacPhail, R. (2011). Effect of humic acid during concurrent chronic waterborne exposure of rainbow trout (Oncorhynchus mykiss) to copper, cadmium and zinc. Ecotox Environment Safety, $74,259-269$.

Klöcking, R. (1992). Humic substances in the global environment and implications in human health. Monopoli, $129 \mathrm{pp}$.

Linfield, W.M., O'Brien, D,J., Serota, S., \& Barauskas, R.A. (1984). Lipid-lipase interaction I. Fat splitting with Candida rugosa. JAOCS, 61(6), 1067-1071.

Marlinda, S. (2016). Humic acids addition for use in diets of tilapia Oreochromis niloticus which contained heavy metals from green mussel Perna viridis. Tesis. 
Sekolah Pasca Sarjana, Institut Pertanian Bogor, $138 \mathrm{hlm}$.

Meinelt, T., Schreckenbach, K., Pietrock, M., Heidrich, S., \& Steinberg, C.E.W. (2008). Humic substances - Part 1: Dissolved humic substances (HS) in aquaculture and ornamental fish breeding. Environmental Science and Pollution Research, 15(1), 17-22.

Mohanta, K.N., Subramanian, S., \& Korikanthimath, V.S. (2013). Evaluation of different animal protein sources in formulating the diets for blue gourami, Trichogaster Trichopterus fingerlings. J. Aquac. Res. Development, 4(2), $7 \mathrm{pp}$.

Muradian, K.K., Utko, N.A., Fraifeld, V., Mozzhukhina, T.G., Pishel, I.N., \& Litoshenko, A.Y. (2002). Superoxide dismutase, catalase and glutathione peroxidase activities in the liver of young and old mice: Linear regression and correlation. Archives of Gerontology and Geriatrics, 35(3), 205-214.

National Research Council [NRC]. (2002). Nutrient requirements of fish and shrimp. Washington D.C. (U.S.): National Academy Press, 114 pp.

Osman, H.A., Ibrahim, T.B., Ali, A.T., \& Derwa, H.I.M. (2009). Field application of humic acid against the effect of cadmium pollution on cultured tilapia Oreochromis niloticus. World Applied Sci. J., 6(11), 1569-1575.

Pompe, S., Bubner, M., Denecke, M.A., Reich, T., Brachmann, Á., Geipel, G., \& Nitsche, H. (1996). A comparison of natural humic acids with synthetic humic acid model substances/: Characterization and interaction with uranium (VI). Radiochimica Acta, 74, 1-6.

Rajagopal, S., Venugopalan, V,P., Van Der Velde G., \& Jenner, H.A. (2006). Greening of the coasts: A review of the Perna viridis success story. Aquatic Ecology, 40, 273-297.

Radiarta, I N., Saputra, A., \& Ardi, I. (2011). Analisis spasial kelayakan lahan budidaya kerang hijau (Perna viridis) berdasarkan kondisi lingkungan di Kabupaten Cirebon, Jawa Barat. Jurnal Riset Akuakultur, 6(2), 169-352.

Rasidi, Jusadi, D., Setiawati, M., Yuhana, M., Zairin, Jr.M., \& Sugama, K. (2019). Effect of humic acid addition to feeds with heavy metal cadmium contamination from green mussels on growth performance of Asian seabass. Biotropia, 26(3), 214216.

Ringo, E., Spertad, S., Myklebus, R., Refstie, S., \& Krogdahl, A. (2006). Characterisation of the microbiota associated with intestine of Atlantic cod (Gadus morhua L.). The effect of fish meal, standard soybean meal and a bioprocessed soybean meal. Aquaculture, 261(3), 829-841.

Riani, E., Cordova, M.R., \& Arifin, Z. (2018). Heavy metal pollution and its relation to the malformation of green mussels cultured in Muara Kamal waters, Jakarta Bay, Indonesia. Mar. Pollution Bull., 133, 664-670.

Robin, Supriyono, E., Nirmala, K., Harris, E., Affandi, R., \& Jusadi, D. (2017). Bio-elimination of lead $(\mathrm{Pb})$ from the organs of red tilapia (Oreochromis sp.) using Gliricidia sepium compost as a feed additive. AACL Bioflux, 1(10), 38-47.

Stevenson, F.J. (1994). Humus chemistry-genesis, composition, reactions. New York: John Wiley \& Sons, $443 \mathrm{pp}$.

Walter, H.E. (1984). Method with haemoglobin, casein, and azocoll as substrate. in: Bergmeyer (Ed.). Methods of enzymatic analysis. 3th Ed. Weinheim (JE): Verlag Chemie.

Widanarni, Nopitawati, T., \& Jusadi D. (2015). Screening of probiotic bacteria candidates from gastrointestine tract of pasific white shrimp Litopeneaus vannamei and their effect on the growth performance. Research journal of Microbiology, 10(4), 145-157.

Wills, E.D. (1987). Evaluation of lipid peroxidation in lipid and biological membran. Biochemical Toxicology. New York: John Wiley \& Sons.

Vidacovic, E. (2015). Fungal and mussel protein sources in fish feed. Dissertation. Swedish University of Agricultural Sciences.

Yoruk, M.A., Gul, M., Hayirli, A., \& Macit, M. (2004). The effects of supplementation of humate and probiotic on egg production and quality parameters during the late laying period in hens. Poultry Science, 83, 84-88.

Yýlmaz, S., Ergun, S., Çelik, E.S., \& Yigit, M. (2018). Effects of dietary humic acid on growth performance, haematoimmunological and physiological responses and resistance of rainbow trout, Oncorhynchus mykiss to Yersinia ruckeri. Aquac. Res., p. 1-12. https://doi.org/10.1111/; https://doi.org/ 10.1111/are.13798.

Zheng, W. \& Shiow, Y.W. (2001). Antioxidant activity and phenolic compounds in selected herbs. Journal Agricultural Food Chemistrry, 49(11), 5165-5170. 